(6) OPEN ACCESS

\title{
Consensus recommendations on training and competing in the heat
}

\author{
S Racinais, ${ }^{1}$ J M Alonso, ${ }^{2,3}$ A J Coutts, ${ }^{4}$ A D Flouris, ${ }^{5} 0$ Girard, ${ }^{6}$ J González-Alonso, ${ }^{7}$ \\ C Hausswirth, ${ }^{8}$ O Jay, ${ }^{9} \mathrm{~J} \mathrm{~K}$ W Lee, ${ }^{10,11,12} \mathrm{~N}$ Mitchell, ${ }^{13} \mathrm{G} \mathrm{P}$ Nassis, ${ }^{14} \mathrm{~L} \mathrm{Nybo}^{15}$ \\ B M Pluim, ${ }^{16}$ B Roelands, $^{17}$ M N Sawka, ${ }^{18}$ J Wingo, $^{19}$ J D Périard ${ }^{1}$
}

For numbered affiliations see end of article.

\section{Correspondence to} Dr Sébastien Racinais, Aspetar Orthopaedic and Sports Medicine Hospital, Research and Education Centre, PO Box 29222, Doha, Qatar; sebastien.racinais@aspetar.com

Accepted 9 April 2015

To cite: Racinais $S$, Alonso JM, Coutts AJ, et al. Br I Sports Med Published Online First: [please include Day Month Year] doi:10.1136/bjsports-2015094915

\section{ABSTRACT}

Exercising in the heat induces thermoregulatory and other physiological strain that can lead to impairments in endurance exercise capacity. The purpose of this consensus statement is to provide up-to-date recommendations to optimise performance during sporting activities undertaken in hot ambient conditions. The most important intervention one can adopt to reduce physiological strain and optimise performance is to heat acclimatise. Heat acclimatisation should comprise repeated exercise-heat exposures over 1-2 weeks. In addition, athletes should initiate competition and training in a euhydrated state and minimise dehydration during exercise. Following the development of commercial cooling systems (eg, cooling-vest), athletes can implement cooling strategies to facilitate heat loss or increase heat storage capacity before training or competing in the heat. Moreover, event organisers should plan for large shaded areas, along with cooling and rehydration facilities, and schedule events in accordance with minimising the health risks of athletes, especially in mass participation events and during the first hot days of the year. Following the recent examples of the 2008 Olympics and the 2014 FIFA World Cup, sport governing bodies should consider allowing additional (or longer) recovery periods between and during events, for hydration and body cooling opportunities, when competitions are held in the heat.

\section{AIM AND SCOPE}

Most of the major international sporting events such as the Summer Olympics, the FIFA World Cup and the Tour de France-that is, the three most popular events in terms of television audience worldwide-take place during the summer months of the northern hemisphere, and often in hot ambient conditions. On the 23rd and 24th of March 2014, a panel of experts reviewed and discussed the specificities of Training and Competing in the Heat during a topical conference held at Aspetar Orthopaedic and Sports Medicine Hospital in Doha, Qatar. The conference ended with a round-table discussion, which has resulted in this consensus statement.

This document is intended to provide up-to-date recommendations regarding the optimisation of exercise capacity during sporting activities in hot ambient conditions. Given that the performance of short duration activities (eg, jumping and sprinting) is at most marginally influenced, or can even be improved, in hot ambient conditions, ${ }^{1}$ but that prolonged exercise capacity is significantly impaired, ${ }^{2}$ the recommendations provided in this consensus statement focus mainly on prolonged sporting events. For additional information on Training and Competing in the Heat, the reader is referred to the supplement issue published in the Scandinavian Journal of Medicine and Science in Sports, which includes targeted reviews and original manuscripts. ${ }^{3}$

\section{INTRODUCTION}

When exercising in the heat, skin blood flow and sweat rate increase to allow for heat dissipation to the surrounding environment. These thermoregulatory adjustments, however, increase physiological strain and may lead to dehydration during prolonged exercise. Heat stress alone will impair aerobic performance when hyperthermia occurs. ${ }^{2}$ 4-6 Consequently, athletes perform endurance, racket or team-sports events in the heat at a lower work rate than in temperate environments. ${ }^{7-12}$ In addition, dehydration during exercise in the heat exacerbates thermal and cardiovascular strain, ${ }^{13-18}$ and further impairs aerobic performance. $^{2} 1719$ This document contains recommendations and strategies to adopt in order to sustain/enhance performance during training and competition in the heat, as well as to minimise the risk of exertional heat illness. As presented in the first section, the most important intervention one can adopt to reduce physiological strain and optimise performance is to heat acclimatise. Given that dehydration can impair physical performance and exacerbate exercise-induced heat strain, the second section of the consensus statement provides recommendations regarding hydration. The third section highlights the avenues through which it is possible to decrease core and skin temperatures, before and during exercise, via the application of cold garments to the skin such as ice packs, cold towels and cooling vests, as well as through cold water immersion (CWI) or ice slurry ingestion.

Given the lack of data from real competitions, the International Olympic Committee (IOC) recently highlighted the necessity for sports federations, team doctors and researchers to collaborate in obtaining data on the specific population of elite athletes exercising in challenging environments. ${ }^{20}$ Several international sporting federations such as FIFA, FINA, FIVB, IAAF and ITF have responded to this challenge by initiating a surveillance system to assess environmental conditions during competition, along with their adverse outcomes. ${ }^{12}$ 21-23 A number of sporting federations have also edited their guidelines to further reduce the risks of 
exertional heat illness. These guidelines are reviewed in the fourth section of this consensus statement. Recommendations are offered to event organisers and sporting bodies on how to best protect the health of the athlete and sustain/enhance performance during events in the heat.

\section{SECTION 1: HEAT ACCLIMATISATION}

Although regular exercise in temperate conditions elicits partial heat acclimatisation, ${ }^{24}$ it cannot replace the benefits induced by consecutive days of training in the heat. ${ }^{24-27}$ Heat acclimatisation improves thermal comfort and submaximal, as well as maximal, aerobic exercise performance in warm-hot conditions. ${ }^{11} 2829$ The benefits of heat acclimatisation are achieved via increased sweating and skin blood flow responses, plasma volume expansion and hence improved cardiovascular stability (ie, better ability to sustain blood pressure and cardiac output), and fluid-electrolyte balance. ${ }^{19} 3031$ Exercise-heat acclimatisation is therefore essential for athletes preparing competitions in warm-hot environments. ${ }^{30}$ This section describes how to practically implement heat acclimatisation protocols and optimise the benefits in athletes.

\section{Induction of acclimatisation}

Duration

Most adaptations (ie, decreases in heart rate, skin and rectal temperature, increases in sweat rate and work capacity) develop within the first week of heat acclimatisation and more slowly in the subsequent 2 weeks. ${ }^{32-34}$ Adaptations develop more quickly in highly trained athletes (up to half the time) compared with untrained individuals. ${ }^{24} 35$ Consequently, athletes benefit from only a few days of heat acclimatisation, ${ }^{36-38}$ but may require 6-10 days to achieve near complete cardiovascular and sudomotor adaptations, ${ }^{28} 2939$ and as such 2 weeks to optimise aerobic performance (ie, cycling time trial) in hot ambient conditions. ${ }^{11}$

\section{Training}

The principle underlying any heat acclimatisation protocol is an increase in body (core and skin) temperature to induce profuse sweating and increase skin blood flow. ${ }^{19} 30$ Repeated heat-exercise training for $100 \mathrm{~min}$ was originally shown to be efficient at inducing such responses. ${ }^{40}$ Reportedly, exercising daily to exhaustion at $60 \% \mathrm{VO}_{2 \max }$ in hot ambient conditions $\left(40^{\circ} \mathrm{C}, 10 \% \mathrm{RH}\right)$ for $9-12$ consecutive days increases exercise capacity from 48 to 80 min. ${ }^{28}$ Ultimately, the magnitude of adaptation depends on the intensity, duration, frequency and number of heat exposures. ${ }^{30} 31$ For example, Houmard et $a l^{41}$ reported similar physiological adaptations following moderate-intensity short-duration $\left(30-35 \mathrm{~min}, 75 \% \mathrm{VO}_{2 \max }\right)$ and low-intensity long-duration (60 $\mathrm{min}, 50 \% \mathrm{VO}_{2 \max }$ ) exercise.

As acclimatisation develops, constant workload exercise protocols may result in a progressively lower training stimulus (ie, decreases in relative exercise intensity). In turn, this may limit the magnitude of adaptation if the duration and/or the intensity of the heat-exercise training sessions are not increased accordingly. ${ }^{42}$ When possible, an isothermic protocol (eg, controlled hyperthermia to a core temperature of at least $38.5^{\circ} \mathrm{C}$ ) can be implemented to optimise the adaptations. ${ }^{43} 44$ However, isothermic protocols may require greater control and the use of artificial laboratory conditions, which could limit their practicality in the field. Alternatively, it has recently been proposed to utilise a controlled intensity regimen based on heart rate to account for the need to increase absolute intensity and maintain a similar relative intensity throughout the acclimatisation process. ${ }^{31}$ Lastly, athletes can adapt by training outdoors in the heat (ie, acclimatisation) using self-paced exercise, or maintaining their regular training regimen. The efficacy of this practice has been demonstrated with team-sport athletes, ${ }^{45}{ }^{46}$ without interfering with their training regimen.

\section{Environment}

Heat acclimatisation in dry heat improves exercise in humid heat ${ }^{47} 48$ and vice versa. ${ }^{49}$ However, acclimatisation in humid heat evokes higher skin temperatures and circulatory adaptations than in dry heat, potentially increasing maximum skin wettedness and therefore the maximum rate of evaporative heat loss from the skin. ${ }^{30} 3150$ Although scientific support for this practice is still lacking, it may potentially be beneficial for athletes to train in humid heat at the end of their acclimatisation sessions to dry heat to further stress the cardiovascular and thermoregulatory systems. Nevertheless, despite some transfer between environments, other adaptations might be specific to the climate (desert or tropic) and physical activity level. ${ }^{51}$ Consequently, it is recommended that athletes predominantly acclimatise to the environment in which they will compete.

Athletes who do not have the possibility to travel to naturally hot ambient conditions (so-called 'acclimatisation') can train in an artificially hot indoor environment (so-called 'acclimation'). However, while acclimation and acclimatisation share similar physiological adaptations, training outdoors is more specific to the competition setting as it allows athletes to experience the exact nature of the heat stress. ${ }^{52-54}$

\section{Decay and periodisation of short-term acclimatisation}

Heat adaptations decay at different rates with the fastest adaptations also decaying more rapidly. ${ }^{35}$ However, the rate of decay of heat acclimatisation is generally slower than its induction, allowing maintenance of the majority of benefits (eg, heart rate, core temperature) for 2-4 weeks. ${ }^{34} 55-58$ Moreover, during this period, individuals re-acclimatise faster than during the first acclimatisation period $^{57}$ (table 1). These studies are, however, mainly based on physiological markers of heat acclimatisation and the decay in competitive sporting performance remains to be clarified.

\section{Individualised heat acclimatisation}

Heat acclimatisation clearly attenuates physiological strain. ${ }^{59} 60$ However, individual acclimatisation responses may differ and should be monitored using simple indices, such as the lessened heart rate increase during a standard submaximal exercise bout. $^{33}$ 61-63 Other more difficult and likely less sensitive markers for monitoring heat acclimatisation include sweat rate and sodium content, ${ }^{64}$ core temperature ${ }^{33}$ and plasma volume. ${ }^{65}$ The role of plasma volume expansion in heat acclimatisation remains debated, as an artificial increase in plasma volume does not appear to improve thermoregulatory function, ${ }^{66}{ }^{67}$ but the changes in haematocrit during a heat-response test following short-term acclimatisation correlate to individual physical performance. ${ }^{45} 46$ This suggests that plasma volume changes might represent a valuable indicator, even if it is probably not the physiological mechanism improving exercise capacity in the heat. Importantly, measures in a temperate environment cannot be used as a substitute to a test in hot ambient temperatures. ${ }^{45} 4668$

As with its induction, heat acclimatisation decay also varies between individuals. ${ }^{32}$ It is therefore recommended that athletes undergo an acclimatisation procedure months before an important event in the heat to determine their individual rate of adaptation and decay ${ }^{20} 45$ (table 1). 
Table 1 Examples of heat-acclimatisation strategies

\begin{tabular}{|c|c|c|c|c|c|}
\hline & Objective & Duration & Period & Content & Environment \\
\hline $\begin{array}{l}\text { Preseason/in-season } \\
\text { training camp }\end{array}$ & $\begin{array}{l}\text { Enhance/boost the training } \\
\text { stimulus }\end{array}$ & $1-2$ weeks & $\begin{array}{l}\text { Preseason or in } \\
\text { season }\end{array}$ & $\begin{array}{l}\text { Regular or additional training ( } 75-90 \\
\text { min/day) to increase body } \\
\text { temperature and induce profuse } \\
\text { sweating }\end{array}$ & $\begin{array}{l}\text { Natural or artificial heat } \\
\text { stress }\end{array}$ \\
\hline $\begin{array}{l}\text { Target competition } \\
\text { preparatory camp }\end{array}$ & $\begin{array}{l}\text { Optimise future } \\
\text { reacclimatisation and evaluate } \\
\text { individual responses in the heat }\end{array}$ & 2 weeks & $\begin{array}{l}1 \text { month before } \\
\text { competing in the } \\
\text { heat }\end{array}$ & $\begin{array}{l}\text { Regular or additional training, } \\
\text { simulated competition and heat } \\
\text { response test }\end{array}$ & $\begin{array}{l}\text { Equivalent to or more } \\
\text { stressful than target } \\
\text { competition }\end{array}$ \\
\hline $\begin{array}{l}\text { Target competition } \\
\text { final camp }\end{array}$ & $\begin{array}{l}\text { Optimise performance in the } \\
\text { heat }\end{array}$ & $\begin{array}{l}1-2 \text { weeks- } \\
\text { depending on results } \\
\text { of preparatory camp }\end{array}$ & $\begin{array}{l}\text { Just before the } \\
\text { competition }\end{array}$ & Precompetition training & Same as competition \\
\hline
\end{tabular}

\section{Heat-acclimatisation as a training stimulus}

Several recent laboratory or uncontrolled-field studies have reported physical performance improvement in temperate environments following training in the heat. ${ }^{29} 46626970$ Athletes might therefore consider using training camps in hot ambient conditions to improve physical performance in-season ${ }^{62}$ and preseason $^{46}$ (table 1). Bearing in mind that training quality should not be compromised, the athletes benefiting the most from this might be experienced athletes requiring a novel training stimulus, ${ }^{46}$ whereas the benefit for highly-trained athletes with limited thermoregulatory requirement (eg, cycling in cold environments) might be more circumstantial. ${ }^{71}$

\section{Summary of the main recommendations for heat acclimatisation}

- Athletes planning to compete in hot ambient conditions should heat acclimatise (ie, repeated training in the heat) to obtain biological adaptations lowering physiological strain and improving exercise capacity in the heat.

- Heat acclimatisation sessions should last at least $60 \mathrm{~min} /$ day, and induce an increase in body core and skin temperatures, as well as stimulate sweating.

- Athletes should train in the same environment as the competition venue, or if not possible, train indoors in a hot room.

- Early adaptations are obtained within the first few days, but the main physiological adaptations are not complete until $\sim 1$ week. Ideally, the heat acclimatisation period should pass 2 weeks in order to maximise all benefits.

\section{SECTION 2: HYDRATION}

The development of hyperthermia during exercise in hot ambient conditions is associated with a rise in sweat rate, which can lead to progressive dehydration if fluid losses are not minimised by increasing fluid consumption. Exercise-induced dehydration, leading to a hypohydrated state, is associated with a decrease in plasma volume and an increase in plasma osmolality that are proportional to the reduction in total body water. ${ }^{19}$ The increase in the core temperature threshold for vasodilation and sweating at the onset of exercise is closely linked to the ensuing hyperosmolality and hypovolaemia. ${ }^{72} 73$ During exercise, plasma hyperosmolality reduces the sweat rate for any given core temperature and decreases evaporative heat loss. ${ }^{74}$ In addition, dehydration decreases cardiac filling and challenges blood pressure regulation. ${ }^{75-77}$ The rate of heat storage and cardiovascular strain is therefore exacerbated, and the capacity to tolerate exercise in the heat is reduced. ${ }^{78-80}$

Despite decades of studies in this area, ${ }^{81}$ the notion that dehydration impairs aerobic performance in sport settings is not universally accepted and there seems to be a two-sided polarised debate. ${ }^{82-84}$ Numerous studies report that dehydration impairs aerobic performance in the condition that if exercise is performed in warm-hot environments and that body water deficits exceed at least $\sim 2 \%$ of body mass. ${ }^{13} 498185-90$ On the other hand, some recent studies suggest that dehydration up to $4 \%$ body mass does not alter cycling performance under an ecologically valid conditions. ${ }^{82} 8391$ However, these results must be interpreted in context; that is, in well-trained male cyclists typically exercising for $60 \mathrm{~min}$ in ambient conditions up to $33^{\circ} \mathrm{C}$ and $60 \%$ relative humidity, and starting exercise in a euhydrated state. Nonetheless, some have advanced the idea that the detrimental consequences of dehydration have been overemphasised by sports beverage companies. ${ }^{92}$ As such, it has been argued that athletes should drink to thirst. ${ }^{82} 8391$ However, many studies (often conducted prior to the creation and marketing of 'sport-drinks') have repeatedly observed that drinking to thirst often results in body water deficits that may exceed $2-3 \%$ body mass when sweat rates are high and exercise is performed in warm-hot environments. ${ }^{13} 4749$ 93-98 Ultimately, drinking to thirst may be appropriate in many settings, but not in circumstances where severe dehydration is expected (eg, Ironman triathlon). ${ }^{84}$

In competition settings, hydration is dependent on several factors, including fluid availability and the specificities of the events. For example, while tennis players have regular access to fluids due to the frequency of breaks in a match, other athletes such as marathon runners have less opportunity to rehydrate. There are also differences among competitors. Whereas the fastest marathon runners do not consume large volume of fluids and become dehydrated during the race, some slower runners may conversely overhydrate, ${ }^{99}$ with an associated risk of 'water intoxication' (ie, hyponatraemia). ${ }^{100}$ The predisposing factors related to developing hyponatraemia during a marathon include substantial weight gain, a racing time above $4 \mathrm{~h}$, female sex and low body-mass index. ${ }^{101} 102$ Consequently, although the recommendations below for competitive athletes explain how to minimise the impairment in performance associated with significant dehydration and body mass loss (ie, $\geq 2 \%$ ), recreational athletes involved in prolonged exercise should be cautious not to overhydrate during the exercise.

\section{Pre-exercise hydration}

Resting and well-fed humans are generally well hydrated,${ }^{103}$ and the typical variance in day-to-day total body water fluctuates from $0.2 \%$ to $0.7 \%$ of body mass. ${ }^{93} 104$ When exposed to heat stress in the days preceding competition, it may, however, be advisable to remind athletes to drink sufficiently and replace 
electrolyte losses to ensure that euhydration is maintained. Generally, drinking $6 \mathrm{~mL}$ of water per $\mathrm{kg}$ of body mass during this period every $2-3 \mathrm{~h}$, as well as $2-3 \mathrm{~h}$ before training or competition in the heat, is advisable.

There are several methods available to evaluate hydration status, each one having limitations depending on how and when the fluids are lost. ${ }^{105} 106$ The most widely accepted and recommended methods include monitoring body mass changes, measuring plasma osmolality and urine specific gravity. Based on these methods, one is considered euhydrated if daily body mass changes remain $<1 \%$, plasma osmolality is $<290 \mathrm{mmol} / \mathrm{kg}$ and urine specific gravity is $<1.020$. These techniques can be implemented during intermittent competitions lasting for several days (eg, cycling stage race, tennis/team sports tournament) to monitor hydration status. Establishing baseline body mass is important, as daily variations may occur. It is best achieved by measuring post-void nude body mass in the morning on consecutive days after consuming 1-2 L of fluid the prior evening. ${ }^{81}$ Moreover, since exercise, diet and prior drinking influence urine concentration measurements, first morning urine is the preferred assessment time point to evaluate hydration status. ${ }^{81}$ If first morning urine cannot be obtained, urine collection should be preceded by several hours of minimal physical activity, fluid consumption and eating.

\section{Exercise hydration}

Sweat rates during exercise in the heat vary dramatically depending on the metabolic rate, environmental conditions and heat acclimatisation status. ${ }^{107}$ While values ranging from 1.0 to $1.5 \mathrm{~L} /$ $\mathrm{h}$ are common for athletes performing vigorous exercise in hot environments, certain individuals can exceed $2.5 \mathrm{~L} / \mathrm{h} .{ }^{108-111}$ Over the last several decades, mathematical models have been developed to provide sweat loss predictions over a broad range of conditions. ${ }^{112-117}$ While these have proven useful in public health, military, occupational and sports medicine settings, these models require further refinement and individualisation to athletic populations, especially elite athletes.

The main electrolyte lost in sweat is sodium (20-70 $\mathrm{mEq} / \mathrm{L}){ }^{118} 119$ and supplementation during exercise is often required for heavy and 'salty' sweaters to maintain plasma sodium balance. Heavy sweaters may also deliberately increase sodium (ie, salt) intake prior to and following hot weather training and competition to maintain sodium balance (eg, $3.0 \mathrm{~g}$ of salt added to $0.5 \mathrm{~L}$ of a carbohydrate-electrolyte drink). To this effect, the Institute of Medicine ${ }^{103}$ has highlighted that public health recommendations regarding sodium ingestion do not apply to individuals who lose large volumes of sodium in sweat, such as athletes training or competing in the heat. A salt intake that would not compensate sweat sodium losses would result in a sodium deficit that might prompt muscle cramping when reaching $20-30 \%$ of the exchangeable sodium pool. ${ }^{120}$ During exercise lasting longer than $1 \mathrm{~h}$, athletes should therefore aim to consume a solution containing $0.5-0.7 \mathrm{~g} / \mathrm{L}$ of sodium. ${ }^{121-123} \mathrm{In}$ athletes experiencing muscle cramping, it is recommended to increase the sodium supplementation to $1.5 \mathrm{~g} / \mathrm{L}$ of fluid. ${ }^{124}$ Athletes should also aim to include $30-60 \mathrm{~g} / \mathrm{h}$ of carbohydrates in their hydration regimen for exercise lasting longer than $1 \mathrm{~h},{ }^{122}$ and up to $90 \mathrm{~g} / \mathrm{h}$ for events lasting over $2.5 \mathrm{~h} .{ }^{125}$ This can be achieved through a combination of fluids and solid foods.

\section{Post-exercise rehydration}

Following training or competing in the heat, rehydration is particularly important to optimise recovery. If fluid deficit needs to be urgently replenished, it is suggested to replace $150 \%$ of body mass losses within $1 \mathrm{~h}$ following the cessation of exercise, ${ }^{123} 126$ including electrolytes to maintain total body water. From a practical perspective, this may not be achievable for all athletes for various reasons (eg, time, gastrointestinal discomfort). Thus, it is more realistic to replace $100-120 \%$ of body mass losses. The preferred method of rehydration is through the consumption of fluids with foods (eg, including salty food).

Given that exercise in the heat increases carbohydrate metabolism, ${ }^{127}{ }^{128}$ endurance athletes should ensure that not only water and sodium losses are replenished, but carbohydrate stores as well. ${ }^{129}$ To ensure the highest rates of muscle glycogen resynthesis, carbohydrates should be consumed during the first hour after exercise. ${ }^{130}$ Moreover, a drink containing protein (eg, milk) might allow better restoration of fluid balance after exercise than a standard carbohydrate-electrolyte sport drink. ${ }^{131}$ Combining protein $(0.2-0.4 \mathrm{~g} / \mathrm{kg} / \mathrm{h})$ to carbohydrate $(0.8 \mathrm{~g} / \mathrm{kg} / \mathrm{h})$ has also been reported to maximise protein synthesis rates. ${ }^{132}$ Therefore, athletes should consider consuming drinks such as chocolate milk, which has a carbohydrate-to-protein ratio of $4: 1$, as well as sodium, following exercise. ${ }^{133}$

\section{Summary of the main recommendations for hydration}

- Before training and competition in the heat, athletes should drink $6 \mathrm{~mL}$ of fluid per $\mathrm{kg}$ of body mass every $2-3 \mathrm{~h}$, in order to start exercise euhydrated.

- During intense prolonged exercise in the heat, body water mass losses should be minimised (without increasing body weight) to reduce physiological strain and help to preserve optimal performance.

- Athletes training in the heat have higher daily sodium (ie, salt) requirements than the general population. Sodium supplementation might also be required during exercise.

- For competitions lasting several days (eg, cycling stage race, tennis/team sports tournament), simple monitoring techniques such as daily morning body mass and urine specific gravity can provide useful insights into the hydration state of the athlete.

- Adequately rehydrating after exercise-heat stress by providing plenty of fluids with meals is essential. If aggressive and rapid replenishment is needed, then consuming fluids and electrolytes to offset $100-150 \%$ of body mass losses will allow for adequate rehydration.

- Recovery hydration regimens should include sodium, carbohydrates and protein.

\section{SECTION 3: COOLING STRATEGIES}

Skin cooling will reduce cardiovascular strain during exercise in the heat, while whole-body cooling can reduce organ and skeletal muscle temperatures. Several studies carried out in controlled laboratory conditions (eg, uncompensable heat-stress), in many cases with or without reduced fanning during exercise, have reported that precooling can improve endurance, ${ }^{134-140}$ and high-intensity ${ }^{141}$ and intermittent-sprint or repeated-sprint exercise performance. ${ }^{142-145}$ However, several other studies reported no performance benefits of precooling on intermittentsprints or repeated-sprints exercise performance in the heat. ${ }^{142}{ }^{146-148}$ Whole body cooling (including cooling of the exercising muscles) may even be detrimental to performance during a single sprint or the first few repetitions of an effort involving multiple sprints. ${ }^{149} 150$

Therefore, whereas several reviews concluded that cooling interventions can increase prolonged exercise capacity in hot conditions, ${ }^{151-158}$ it has to be acknowledged that most 
laboratory based precooling studies might have overestimated the effect of precooling as compared to an outdoor situation with airflow, ${ }^{159}$ or do not account for the need to warm-up before competing. As a consequence, the effectiveness of cooling in a competitive settings remains equivocal and the recommendations below are limited to prolonged exercise in hot ambient conditions with no or limited air movement.

\section{Cold-water immersion}

A range of CWI protocols are available (for reviews see 156 160-162), but the most common techniques are whole body CWI for $\sim 30 \mathrm{~min}$ at a water temperature of $22-30^{\circ} \mathrm{C}$, or body segment (eg, legs) immersion at lower temperatures $\left(10-18^{\circ} \mathrm{C}\right) .{ }^{156}$ However, cooling of the legs/muscles will decrease nerve conduction and muscle contraction velocities, ${ }^{1}$ and athletes might therefore need to re-warm-up before competition. Consequently, other techniques involving cooling garments have been developed to selectively cool the torso, which may prevent the excessive cooling of active muscles while reducing overall thermal and cardiovascular strain.

\section{Cooling garments}

Building on the early practice of using iced towels for cooling purposes, several manufacturers have designed ice-cooling jackets to cool athletes before or during exercise. ${ }^{137} 142163164$ The decrease in core temperature is smaller with a cooling vest than with CWI or mixed-cooling methods, ${ }^{158}$ but cooling garments present the advantage of lowering skin temperature, and thus reducing cardiovascular strain and, eventually, heat storage. ${ }^{165}$ Cooling garments are practical in reducing skin temperature without reducing muscle temperature, and athletes can wear them during warm-up or recovery breaks.

\section{Cold fluid ingestion}

Cold fluids can potentially enhance endurance performance when ingested before, ${ }^{166}{ }^{167}$ but not during, ${ }^{168}{ }^{169}$ exercise. Indeed, it is suggested that a downside of ingesting cold fluids during exercise might be a reduction in sweating and therefore skin surface evaporation, ${ }^{170}$ due to the activation of thermoreceptors probably located in the abdominal area. ${ }^{171}$

\section{Ice-slurry beverages}

Based on the theory of enthalpy, ice requires substantially more heat energy $(334 \mathrm{~J} / \mathrm{g})$ to cause a phase change from solid to liquid $\left(\right.$ at $\left.0^{\circ} \mathrm{C}\right)$ compared with the energy required to increase the temperature of water $\left(4 \mathrm{~J} / \mathrm{g} /{ }^{\circ} \mathrm{C}\right)$. As such, ice slurry may be more efficient than cold-water ingestion in cooling athletes. However, it is not yet clear if the proportional reduction in sweating observed with the ingestion of cold water during exercise $^{170}$ occurs with ice slurry ingestion. Several recent reports support the consumption of an ice-slurry beverage since performance during endurance or intermittent-sprint exercise is improved following the ingestion of an ice-slurry beverage $\left(\sim 1 \mathrm{~L}\right.$ crushed ice at $\left.\leq 4^{\circ} \mathrm{C}\right)$ either prior to ${ }^{140} 172173$ or during exercise, ${ }^{174}$ but no benefit was evident when consumed during the recovery period between two exercise bouts in another study. ${ }^{175}$ Consequently, ingestion of ice-slurry may be a practical complement or alternative to external cooling methods, ${ }^{155}$ but more studies are still required during actual outdoor competitions.

\section{Mixed methods cooling strategies}

Combining techniques (ie, using both external and internal cooling strategies) has a higher cooling capacity than the same techniques used in isolation, allowing for greater benefit on exercise performance. ${ }^{158}$ Indeed, mixed methods have proven beneficial when applied to professional football players during competition in the tropics, ${ }^{176}$ lacrosse players training in hot environments $^{177}$ and cyclists simulating a competition in a laboratory. ${ }^{139}$ In a sporting context, this can be achieved by combining simple strategies, such as the ingestion of ice-slurry, wearing cooling vests and providing fanning.

\section{Cooling to improve performance between subsequent bouts of exercise}

There is evidence supporting the use of CWI (5 to $12 \mathrm{~min}$ in $14^{\circ} \mathrm{C}$ water) during the recovery period (eg, $15 \mathrm{~min}$ ) separating intense exercise bouts in the heat to improve subsequent performance. ${ }^{178} 179$ The benefits of this practice would relate to a redistribution of the blood flow, probably from the skin to the central circulation, ${ }^{180}$ as well as a psychological (ie, placebo) effect. ${ }^{181}$ In terms of internal cooling, the ingestion of cold water $^{182}$ or ice-slurry ${ }^{175}$ during the recovery period might attenuate heat strain in the second bout of work, but not necessarily significantly improve performance. ${ }^{175}$ Together, these studies suggest that cooling might help recovery from intense exercise in uncompensable laboratory heat-stress and, in some cases, might improve performance in subsequent intense exercise bouts. The effects of aggressive cooling versus simply resting in the prevailing hot ambient conditions, or in cooler conditions, remains to be validated in a competition setting (eg, half time in team-sports).

\section{Summary of the main recommendations for cooling}

- Cooling methods include external (eg, application of iced garments, towels, water immersion or fanning) and internal (eg, ingestion of cold fluids or ice-slurry) methods.

- Precooling may benefit sporting activities involving sustained exercise (eg, middle and long distance running, cycling, tennis and team sports) in warm-hot environments. Internal methods (ie, ice slurry) can be used during exercise, whereas tennis and team sport athletes can also implement mixed cooling methods during breaks.

- Such practice may not be viable for explosive or shorter duration events (eg, sprinting, jumping, throwing) conducted in similar conditions.

- A practical approach in hot-humid environments might be the use of fans and commercially available ice cooling vests, which can provide effective cooling without impairing muscle temperature. In any case, cooling methods should be tested and individualised during training to minimise disruption to the athlete.

\section{SECTION 4: RECOMMENDATIONS FOR EVENT ORGANISERS}

The most common set of recommendations followed by event organisers to reschedule or cancel an event is based on the wet bulb globe temperature (WBGT) index empirically developed by the US military, popularised in sports medicine by the American College of Sports Medicine ${ }^{183}$ and adopted by various sporting federations (table 2). However, WBGT might underestimate heat stress risk when sweat evaporation is restricted (ie, high humidity and/or low air movement). ${ }^{184}$ Thus, corrected recommendations have been proposed ${ }^{185}$ (table 3). Moreover, the WBGT is a climatic index and does not account for metabolic heat production or clothing and therefore cannot predict heat dissipation. ${ }^{19}$ Therefore, the recommendations below provide guidelines for various sporting activities rather than fixed cut-offs based on the WBGT index. 
Table 2 Examples of recommended actions by various sporting governing bodies based on the WBGT

\begin{tabular}{|c|c|c|c|}
\hline $\begin{array}{l}\text { WBGT } \\
\left({ }^{\circ} \mathrm{C}\right)\end{array}$ & Organization & Athlete concerned & Recommendation \\
\hline 32.3 & ACSM & $\begin{array}{l}\text { Acclimatised, fit and } \\
\text { low-risk individuals }\end{array}$ & Participation cut-off \\
\hline 32.2 & ITF & $\begin{array}{l}\text { Junior and wheelchair } \\
\text { tennis players }\end{array}$ & $\begin{array}{l}\text { Immediate suspension } \\
\text { of play }\end{array}$ \\
\hline 32.2 & WTA & Female tennis players & $\begin{array}{l}\text { Immediate suspension } \\
\text { of play }\end{array}$ \\
\hline 32.0 & FIFA & Football players & $\begin{array}{l}\text { Additional cooling } \\
\text { break at } 30 \text { and } 75 \mathrm{~min}\end{array}$ \\
\hline 30.1 & ACSM & $\begin{array}{l}\text { Non-acclimatised, unfit } \\
\text { and high-risk } \\
\text { individuals }\end{array}$ & Participation cut-off \\
\hline 30.1 & ITF-WTA & $\begin{array}{l}\text { Junior and female } \\
\text { tennis players }\end{array}$ & $\begin{array}{l}10 \text { min break between } \\
2 \text { nd and 3rd set }\end{array}$ \\
\hline 30.1 & ITF & $\begin{array}{l}\text { Wheelchair tennis } \\
\text { players }\end{array}$ & $\begin{array}{l}\text { Suspension of play at } \\
\text { the end of the set in } \\
\text { progress }\end{array}$ \\
\hline 28.0 & ITF & $\begin{array}{l}\text { Wheelchair tennis } \\
\text { players }\end{array}$ & $\begin{array}{l}15 \text { min break between } \\
2 \text { nd and 3rd set }\end{array}$ \\
\hline 28.0 & Australian Open & Tennis players & $\begin{array}{l}10 \text { min break between } \\
2 \text { nd and 3rd set }\end{array}$ \\
\hline 21.0 & $\begin{array}{l}\text { Marathon in } \\
\text { northern } \\
\text { latitudes }\end{array}$ & $\begin{array}{l}\text { Runners in mass } \\
\text { participation events }\end{array}$ & Cancel marathon \\
\hline \multicolumn{4}{|c|}{$\begin{array}{l}\text { Data from Armstrong et al, }{ }^{183} \text { Roberts } \\
\text { http://www.fifa.com/aboutfifa/footballdevelopment/medical/playershealth/risks/heat. } \\
\text { html, http://www.itftennis.com/media/194281/194281.pdf. } \\
\text { http://www.itftennis.com/media/195690/195690.pdf. } \\
\text { http///www.wtatennis.com/SEWTATour-Archive/Achive/AboutTheTour/rules2015.pdf. } \\
\text { http://www.ausopen.com/en_AU/event_guide/a_Z_guide.html. } \\
\text { ACSM, American College of Sports Medicine; ITF, IIternational Tennis Federation; } \\
\text { WBGT, wet bulb globe temperature; WTA, Women's Tennis Association. }\end{array}$} \\
\hline
\end{tabular}

\section{Cancelling an event or implementing countermeasures?}

Further to appropriate scheduling of any event with regard to expected environmental conditions, protecting athlete health might require stopping competition when combined exogenous and endogenous heat loads cannot be physiologically compensated. The environmental conditions in which the limit of compensation is exceeded depends on several factors, such as metabolic heat production (depending on workload and efficiency/economy), athlete morphology (eg, body surface area to mass ratio), acclimatisation state (eg, sweat rate) and clothing. It is therefore problematic to establish universal cut-off values across different sporting disciplines. Environmental indices

Table 3 Corrected estimation of the risk of exertional heat illness based on the wet bulb globe temperature (WBGT) taking into account that WBGT underestimates heat stress under high humidity

\begin{tabular}{llc}
\hline Estimated risk & WBGT $\left({ }^{\circ} \mathrm{C}\right)$ & Relative humidity $(\%)$ \\
\hline Moderate & 24 & 50 \\
Moderate & 20 & 75 \\
Moderate & 18 & 100 \\
High & 28 & 50 \\
High & 26 & 75 \\
High & 24 & 100 \\
Excessive & 33 & 50 \\
Excessive & 29 & 75 \\
Excessive & 28 & 100
\end{tabular}

Adapted from the categories proposed by Gonzalez ${ }^{185}$ to estimate the risk of exertional heat illness during a marathon. should be viewed as recommendations for event organisers to implement preventive countermeasures to offset the potential risk of heat illness. The recommended countermeasures include adapting the rules and regulations with regard to cooling breaks and the availability of fluids (time and locations), as well as providing active cooling during rest periods. It is also recommended that medical response protocols and facilities to deal with cases of exertional heat illnesses be in place.

\section{Specificity of the recommendations \\ Differences among sports}

Hot ambient conditions impair endurance exercise such as marathon running, ${ }^{7}$ but potentially improve short duration events such as jumping or sprinting. ${ }^{1}$ In many sports, athletes adapt their activity according to the environmental conditions. For example, compared to cooler conditions, football players decrease the total distance covered or the distance covered at high intensity during a game, but maintain their sprinting activity/ability, ${ }^{9} 12186$ while tennis players reduce point duration ${ }^{8}$ or increase the time between points ${ }^{10}$ when competing in the heat (WBGT $\sim 34^{\circ} \mathrm{C}$ ). Event organisers and international federations should therefore acknowledge and support such behavioural thermoregulatory strategies by adapting the rules and refereeing accordingly.

\section{Differences among individuals within a given sport}

When comparing two triathlon races held in Melbourne, in similar environmental conditions (ie, WBGT raising from 22 to $27^{\circ} \mathrm{C}$ during each race), 2 months apart, Gosling et al ${ }^{187}$ observed 15 cases of exertional heat illness (including 3 heat strokes) in the first race that was held in unseasonably hot weather at the start of summer, but no cases in the second race. This suggests that the risk of heat illness was increased in competitors who were presumably not seasonally heat acclimatised $^{187}$ and supports many earlier studies regarding increased risk of heat illness in early summer, or with hot weather spikes. ${ }^{188}$ Nevertheless, exertional heat stroke can occur in individuals who are well acclimatised and have performed similar activities several times before, as they may suffer from prior viral infection or similar ailment. ${ }^{19}$ In one of the very few epidemiological studies linking WBGT to illness in athletes, Bahr et $a l^{22}$ investigated 48 beach volleyball matches (World Tour and World Championships), over 3 years. They reported only one case of a heat-related medical forfeit, which was related to an athlete with compromised fluid balance due to a 3-day period of acute gastroenteritis. ${ }^{22}$ Moreover, while healthy runners can also finish a half-marathon in warm and humid environments without developing heat illness, ${ }^{189}$ exertional heat stroke has been shown to occur during a cool weather marathon in a runner recovering from a viral infection. ${ }^{190}$

In fact, prior viral infection is emerging as a potentially important risk factor for heat injury/stroke. ${ }^{19} 191$ Event organisers should therefore pay particular medical attention to all populations potentially at a greater risk, including participants currently sick or recovering from a recent infection, those with diarrhoea, recently vaccinated, with limited heat dissipation capacity due to medical conditions (eg, Paralympic athletes), or individuals involved in sports with rules restricting heat dissipation capacity (eg, protective clothing/equipment). Unacclimatised participants are also to be considered at risk. Although it is impractical to screen every athlete during large events, organisers are encouraged to provide information, possibly in registration kits, advising all athletes of the risk associated with participation under various potential compromised states and suggesting countermeasures. 


\section{Summary of the main recommendations for event organisers}

- The WBGT is an environmental heat stress index and not a representation of human heat strain. It is therefore difficult to establish absolute participation cut-off values across sports for different athletes and we rather recommend implementing preventive countermeasures, or evaluating the specific demands of the sport when preparing extreme heat policies.

- Countermeasures include scheduling the start time of events based on weather patterns, adapting the rules and refereeing to allow extra breaks or longer recovery periods, and developing a medical response protocol and cooling facilities.

- Event organisers should pay particular attention to all 'at risk' populations. Given that unacclimatised participants (mainly in mass participation events) are at a higher risk for heat-illness, organisers should properly advise participants of the risk associated with participation, or consider cancelling an event in the case of unexpected or unseasonably hot weather.

\section{OVERALL CONCLUSION}

Our current knowledge on heat stress is mainly derived from military and occupational research fields, while the input from sport sciences is more recent. Based on this literature, athletes should train for at least 1 week and ideally 2 weeks to acclimatise using a comparable degree of heat stress as the target competition. They should also be cautious to undertake exercise in a euhydrated state and minimise body water deficits (as monitored by body mass losses) through proper rehydration during exercise. They can also implement specific countermeasures (eg, cooling methods) to reduce heat storage and physiological strain during competition and training, especially when the environmental conditions are uncompensable. Event organisers and sports governing bodies can support athletes by allowing additional (or longer) recovery periods for enhanced hydration and cooling opportunities during competitions in the heat.

\section{Author affiliations}

${ }^{1}$ Athlete Health and Performance Research Centre, Aspetar Orthopaedic and Sports Medicine Hospital, Doha, Qatar

${ }^{2}$ Sports Medicine Department, Aspetar Orthopaedic and Sports Medicine Hospital, Doha, Qatar

${ }^{3}$ Medical and Anti-doping Commission, International Association of Athletics Federations (IAAF), Montecarlo, Monaco

${ }^{4}$ Sport and Exercise Discipline Group, University of Technology Sydney (UTS), Australia

${ }^{5}$ FAME Laboratory, Department of Physical Education and Sport Science, University of Thessaly, Trikala, Greece

${ }^{6}$ Department of Physiology, Faculty of Biology and Medicine, ISSUL, Institute of Sport Sciences, University of Lausanne, Lausanne, Switzerland

${ }^{7}$ Department of Life Sciences, Centre for Sports Medicine and Human Performance, College of Health and Life Sciences, Brunel University London, Uxbridge, UK

${ }^{8}$ Research Department, Laboratory of Sport, Expertise and Performance, French National Institute of Sport (INSEP), Paris, France

${ }^{9}$ Discipline of Exercise and Sport Science, Faculty of Health Sciences, University of Sydney, Lidcombe, Australia

${ }^{10}$ Defence Medical and Environmental Research Institute, DSO National Laboratories, Singapore, Singapore

${ }^{11}$ Yong Loo Lin School of Medicine, National University of Singapore, Singapore, Singapore

${ }_{12}^{12}$ Lee Kong Chian School of Medicine, Nanyang Technological University, Singapore, Singapore

${ }^{13}$ British Cycling and 'Sky Pro Cycling', National Cycling Centre, Manchester, UK

${ }^{14}$ National Sports Medicine Programme, Excellence in Football Project, Aspetar, Qatar Orthopaedic and Sports Medicine Hospital, Doha, Qatar

${ }^{15}$ Department of Nutrition, Exercise and Sport, Section of Human Physiology, University of Copenhagen, Copenhagen, Denmark

${ }^{16}$ Medical Department, Royal Netherlands Lawn Tennis Association (KNLTB),

Amersfoort, The Netherlands
${ }^{17}$ Department of Human Physiology, Vrije Universiteit Brussel, Brussels, Belgium

${ }^{18}$ School of Applied Physiology, College of Science, Georgia Institute of Technology, Atlanta, Georgia, USA

${ }^{19}$ Department of Kinesiology, University of Alabama, Tuscaloosa, USA

Twitter Follow Dr Sébastien Racinais at @SebRacinais

Acknowledgements The authors thank the following conference attendees for their participation in the two days of discussion: Carl Bradford, Martin Buchheit, Geoff Coombs, Simon Cooper, Kevin De Pauw, Sheila Dervis, Abdulaziz Farooq, Oliver Gibson, Mark Hayes, Carl James, Stefanie Keiser, Luis Lima, Alex Lloyd, Erin McLeave, Jessica Mee, Nicholas Ravanelli, Jovana Smoljanic, Steve Trangmar, James Tuttle, Jeroen Van Cutsem and Matthijs Veltmeijer. Bart Roelands is a postdoctoral fellow of the Fund for Scientific Research Flanders (FWO).

\section{Competing interests None declared.}

Funding José González-Alonso has received research funding from the Gatorade Sports Science Institute, Pepsico. Michael N Sawka was a member of the Gatorade Sports Science Institute Expert Panel in 2014.

Provenance and peer review Not commissioned; internally peer reviewed.

Open Access This is an Open Access article distributed in accordance with the Creative Commons Attribution Non Commercial (CC BY-NC 4.0) license, which permits others to distribute, remix, adapt, build upon this work non-commercially, and license their derivative works on different terms, provided the original work is properly cited and the use is non-commercial. See: http://creativecommons.org/ licenses/by-nc/4.0/

\section{REFERENCES}

1 Racinais S, Oksa J. Temperature and neuromuscular function. Scand J Med Sci Sports 2010;20(Suppl 3):1-18.

2 Nybo L, Rasmussen P, Sawka MN. Performance in the heat-physiological factors of importance for hyperthermia-induced fatigue. Compr Physiol 2014;4:657-89.

3 Periard J, Racinais S. Editorial: Training and competing in the heat. Scand J Med Sci Sports 2015;25(Suppl 1):2-3.

4 Rowell LB. Human cardiovascular adjustments to exercise and thermal stress. Physiol Rev 1974;54:75-159.

5 Galloway SD, Maughan RJ. Effects of ambient temperature on the capacity to perform prolonged cycle exercise in man. Med Sci Sports Exerc 1997:29:1240-9.

6 Périard JD, Cramer MN, Chapman PG, et al. Cardiovascular strain impairs prolonged self-paced exercise in the heat. Exp Physiol 2011;96:134-44.

7 Ely MR, Cheuvront SN, Roberts WO, et al. Impact of weather on marathon-running performance. Med Sci Sports Exerc 2007;39:487-93.

8 Morante SM, Brotherhood JR. Autonomic and behavioural thermoregulation in tennis. Br J Sports Med 2008;42:679-85; discussion 685.

9 Mohr M, Nybo L, Grantham J, et al. Physiological responses and physical performance during football in the heat. PLOS ONE 2012;7:e39202.

10 Périard JD, Racinais S, Knez WL, et al. Thermal, physiological and perceptual strain mediate alterations in match-play tennis under heat stress. Br J Sports Med 2014;48(Suppl 1):i32-8.

11 Racinais S, Périard JD, Karlsen A, et al. Effect of heat and heat acclimatization on cycling time trial performance and pacing. Med Sci Sports Exerc 2015:47:601-6.

12 Nassis GP, Brito J, Dvorak J, et al. The association of environmental heat stress with performance: analysis of the 2014 FIFA World Cup Brazil. Br J Sports Med 2015;49:609-13.

13 Adolph EF. Physiology of Man in the Desert. New York: Interscience, 1947.

14 Strydom NB, Holdsworth LD. The effects of different levels of water deficit on physiological responses during heat stress. Int Z Angew Physiol 1968;26:95-102.

15 Sawka MN, Young AJ, Francesconi RP, et al. Thermoregulatory and blood responses during exercise at graded hypohydration levels. J Appl Physiol 1985;59:1394-401.

16 Montain SJ, Coyle EF. Influence of graded dehydration on hyperthermia and cardiovascular drift during exercise. J Appl Physiol 1992;73:1340-50.

17 González-Alonso J, Crandall CG, Johnson JM. The cardiovascular challenge of exercising in the heat. J Physiol 2008;586:45-53.

18 Trangmar SJ, Chiesa ST, Stock CG, et al. Dehydration affects cerebral blood flow but not its metabolic rate for oxygen during maximal exercise in trained humans. J Physiol 2014;592:3143-60.

19 Sawka MN, Leon LR, Montain SJ, et al. Integrated physiological mechanisms of exercise performance, adaptation, and maladaptation to heat stress. Compr Physiol 2011;1:1883-928.

20 Bergeron MF, Bahr R, Bärtsch P, et al. International Olympic Committee consensus statement on thermoregulatory and altitude challenges for high-level athletes. $\mathrm{Br} J$ Sports Med 2012;46:770-9.

21 Grantham J, Cheung SS, Connes P, et al. Current knowledge on playing football in hot environments. Scand J Med Sci Sports 2010;20(Suppl 3):161-7. 
22 Bahr R, Reeser JC. New guidelines are needed to manage heat stress in elite sports--The Fédération Internationale de Volleyball (FIVB) Heat Stress Monitoring Programme. Br J Sports Med 2012;46:805-9.

23 Mountjoy M, Alonso J-M, Bergeron MF, et al. Hyperthermic-related challenges in aquatics, athletics, football, tennis and triathlon. Br J Sports Med 2012;46:800-4.

24 Armstrong LE, Pandolf KB. Physical training, cardiorespiratory physical fitness and exercise-heat tolerance. In: Pandolf KB, Sawka MN, Gonzalez RR. eds. Physiology and Environmental Medicine at Terrestrial Extremes. Indianapolis, IN: Physiology and Environmental Medicine at Terrestrial Extremes, 1988:199-226.

25 Gisolfi C, Robinson S. Relations between physical training, acclimatization, and heat tolerance. J App/ Physiol 1969;26:530-4.

26 Nadel ER, Pandolf $\mathrm{KB}$, Roberts MF, et al. Mechanisms of thermal acclimation to exercise and heat. J Appl Physiol 1974;37:515-20.

27 Roberts MF, Wenger CB, Stolwijk JA, et al. Skin blood flow and sweating changes following exercise training and heat acclimation. J App/ Physiol 1977;43:133-7.

28 Nielsen B, Hales JR, Strange $S$, et al. Human circulatory and thermoregulatory adaptations with heat acclimation and exercise in a hot, dry environment. J Physiol 1993;460:467-85

29 Lorenzo S, Halliwill JR, Sawka MN, et al. Heat acclimation improves exercise performance. J App/ Physiol 2010;109:1140-7.

30 Sawka MN, Wenger CB, Pandolf KB. Thermoregulatory responses to acute exercise-heat stress and heat acclimation. In: Fregly MJ, Blatteis CM. eds. Handbook of Physiology section 4, environmental physiology. New York: Oxford University Press 1996:157-85.

31 Periard J, Racinais S, Sawka MN. Adaptations and mechanisms of human heat acclimation: Applications for competitive athletes and sports. Scand J Med Sci Sports 2015;25(Suppl 1):20-38.

32 Robinson S, Turrell ES, Belding HS, et al. Rapid acclimatization to work in hot climates. Am J Physiol 1943;140:168-76.

33 Ladell WS. Assessment of group acclimatization to heat and humidity. J Physiol 1951;115:296-312.

34 Flouris $A D$, Poirier MP, Bravi $A$, et al. Changes in heart rate variability during the induction and decay of heat acclimation. Eur J App/ Physiol 2014;114:2119-28.

35 Pandolf KB, Burse RL, Goldman RF. Role of physical fitness in heat acclimatisation, decay and reinduction. TERG 1977;20:399-408.

36 Sunderland C, Morris JG, Nevill ME. A heat acclimation protocol for team sports. Br J Sports Med 2008;42:327-33.

37 Garrett AT, Rehrer NJ, Patterson MJ. Induction and decay of short-term heat acclimation in moderately and highly trained athletes. Sports Med 2011:41:757-71.

38 Chalmers S, Esterman A, Eston R, et al. Short-term heat acclimation training improves physical performance: a systematic review, and exploration of physiological adaptations and application for team sports. Sports Med 2014;44:971-88

39 Karlsen A, Nybo L, Norgaard SJ, et al. Time course of natural heat acclimatization in well-trained cyclists during a 2-week training camp in the heat. Scand J Med Sci Sports 2015;25(Suppl 1):240-49.

40 Lind AR, Bass DE. Optimal exposure time for development of acclimatization to heat. Fed Proc 1963;22:704-8.

41 Houmard JA, Costill DL, Davis JA, et al. The influence of exercise intensity on heat acclimation in trained subjects. Med Sci Sports Exerc 1990;22:615-20.

42 Taylor NAS. Human heat adaptation. Compr Physiol 2014;4:325-65.

43 Patterson MJ, Stocks JM, Taylor NAS. Sustained and generalized extracellular fluid expansion following heat acclimation. J Physiol 2004;559:327-34.

44 Garrett AT, Goosens NG, Rehrer NJ, et al. Induction and decay of short-term heat acclimation. Eur J Appl Physiol 2009;107:659-70.

45 Racinais S, Mohr M, Buchheit M, et al. Individual responses to short-term heat acclimatisation as predictors of football performance in a hot, dry environment. Br J Sports Med 2012;46:810-15.

46 Racinais S, Buchheit M, Bilsborough J, et al. Physiological and performance responses to a training camp in the heat in professional Australian football players. Int J Sports Physiol Perform 2014;9:598-603.

47 Bean WB, Eichna LA. Performance in relation to environmental temperature. Reactions of normal young men to simulated desert environments. Fed Proc 1943;2:144-58.

48 Fox RH, Goldsmith R, Hampton IF, et al. Heat acclimatization by controlled hyperthermia in hot-dry and hot-wet climates. J App/ Physiol 1967;22:39-46.

49 Eichna LW, Bean WB, William F. Performance in relation to environmental temperature. Reactions of normal young men to hot, humid (simulated jungle) environment. Bull Johns Hopkins Hosp 1945;76:25058.

50 Candas V, Libert JP, Vogt JJ. Influence of air velocity and heat acclimation on human skin wettedness and sweating efficiency. J App/ Physiol 1979;47:1194-200.

51 Sawka MN, Cheuvront SN, Kolka MA. Human adaptation to heat stress. In: Nose $\mathrm{H}$, Mack GW, Imaizumi K. eds. Exercise, Nutrition and Environmental Stress. Traverse City, MI: Exercise, Nutrition and Environmental Stress, 2003:129-53.

52 Hellon RF, Jones RM, MacPherson RK, et al. Natural and artificial acclimatization to hot environments. J Physiol 1956;132:559-76.
53 Edholm OG. The physiology of adaptation. Eugen Rev 1966;58:136-42.

54 Armstrong L, Maresh C. The induction and decay of heat acclimatisation in trained athletes. Sports Med 1991;12:302.

55 Dresoti AO. The results of some investigations into the medical aspects of deep mining on the Witwatersrand. J Chem Metal Mining Soc S Afr 1935;6: 102-29.

56 Lind AR. Physiologic responses to heat. In: Licht S. ed. Medical Climatology. Baltimore, MD: Medical Climatology, 1964:164-95.

57 Weller AS, Linnane DM, Jonkman AG, et al. Quantification of the decay and re-induction of heat acclimation in dry-heat following 12 and 26 days without exposure to heat stress. Eur J Appl Physiol 2007;102:57-66.

58 Daanen HAM, Jonkman AG, Layden JD, et al. Optimising the acquisition and retention of heat acclimation. Int J Sports Med 2011;32:822-8.

59 Eichna LW, Park CR, Nelson N, et al. Thermal regulation during acclimatization in a hot, dry (desert type) environment. Am J Physiol 1950;163:585-97.

60 MacDonald DKC, Wyndham CH. Heat transfer in man. J Appl Physiol 1950:3:342-64.

61 Lee D. A Basis for the Study of Man's Reaction to Tropical Climates. Univ Qld Pap Dept Physiology 1940;1:86.

62 Buchheit M, Voss SC, Nybo L, et al. Physiological and performance adaptations to an in-season soccer camp in the heat: associations with heart rate and heart rate variability. Scand J Med Sci Sports 2011;21:e477-85.

63 Buchheit M, Racinais S, Bilsborough J, et al. Adding heat to the live-high train-low altitude model: a practical insight from professional football. Br J Sports Med 2013;47(Suppl 1):i59-69.

64 Dill DB, Hall FG, Edwards HT. Changes in composition of sweat during acclimatization to heat. Am J Physiol 1938;123:412-9.

65 Glaser EM. Acclimatization to heat and cold. J Physiol 1950;110:330-7.

66 Sawka MN, Coyle EF. Influence of body water and blood volume on thermoregulation and exercise performance in the heat. Exerc Sport Sci Rev 1999;27:167-218.

67 Watt MJ, Garnham AP, Febbraio MA, et al. Effect of acute plasma volume expansion on thermoregulation and exercise performance in the heat. Med Sci Sports Exerc 2000;32:958-62.

68 Armstrong LE, Hubbard RW, DeLuca JP, et al. Evaluation of a temperate environment test to predict heat tolerance. Eur J App/ Physiol Occup Physiol 1987;56:384-9.

69 Hue 0 , Antoine-Jonville S, Sara F. The effect of 8 days of training in tropical environment on performance in neutral climate in swimmers. Int I Sports Med 2007;28:48-52.

70 Scoon GSM, Hopkins WG, Mayhew S, et al. Effect of post-exercise sauna bathing on the endurance performance of competitive male runners. J Sci Med Sport 2007;10:259-62.

71 Karlsen A, Racinais S, Jensen MV, et al. Heat acclimatization does not improve V02max or cycling performance in a cool climate in trained cyclists. Scand J Med Sci Sports 2015;25(Suppl 1):269-76.

72 Nadel ER, Fortney SM, Wenger CB. Effect of hydration state of circulatory and thermal regulations. J App/ Physiol 1980:49:715-21.

73 Fortney SM, Wenger CB, Bove JR, et al. Effect of hyperosmolality on control of blood flow and sweating. J App/ Physiol 1984;57:1688-95.

74 Montain SJ, Latzka WA, Sawka MN. Control of thermoregulatory sweating is altered by hydration level and exercise intensity. J Appl Physiol 1995;79: 1434-9.

75 González-Alonso J, Mora-Rodríguez R, Below PR, et al. Dehydration reduces cardiac output and increases systemic and cutaneous vascular resistance during exercise. J Appl Physiol 1995;79:1487-96.

76 González-Alonso J, Calbet JA, Nielsen B. Muscle blood flow is reduced with dehydration during prolonged exercise in humans. J Physio/ 1998;513(Pt 3):895-905.

77 Stöhr EJ, González-Alonso J, Pearson J, et al. Dehydration reduces left ventricular filling at rest and during exercise independent of twist mechanics. J App/ Physiol 2011;111:891-7.

78 Sawka MN, Toner MM, Francesconi RP, et al. Hypohydration and exercise: effects of heat acclimation, gender, and environment. J Appl Physiol 1983;55:1147-53.

79 Sawka MN. Physiological consequences of hypohydration: exercise performance and thermoregulation. Med Sci Sports Exerc 1992;24:657-70.

80 González-Alonso J, Mora-Rodríguez R, Coyle EF. Stroke volume during exercise: interaction of environment and hydration. Am J Physiol Heart Circ Physiol 2000;278:H321-30.

81 Cheuvront SN, Kenefick RW. Dehydration: physiology, assessment, and performance effects. Compr Physiol 2014;4:257-85.

82 Goulet EDB. Effect of exercise-induced dehydration on time-trial exercise performance: a meta-analysis. Br J Sports Med 2011;45:1149-56.

83 Goulet EDB. Effect of exercise-induced dehydration on endurance performance: evaluating the impact of exercise protocols on outcomes using a meta-analytic procedure. Br J Sports Med 2013;47:679-86.

84 Cotter JD, Thornton SN, Lee JK, et al. Are we being drowned in hydration advice? Thirsty for more? Extrem Physiol Med 2014;3:18. 
85 Below PR, Mora-Rodríguez R, González-Alonso J, et al. Fluid and carbohydrate ingestion independently improve performance during $1 \mathrm{~h}$ of intense exercise. Med Sci Sports Exerc 1995;27:200-10.

86 Cheung SS, McLellan TM. Heat acclimation, aerobic fitness, and hydration effects on tolerance during uncompensable heat stress. J Appl Physiol 1998;84:1731-9.

87 Ebert TR, Martin DT, Bullock N, et al. Influence of hydration status on thermoregulation and cycling hill climbing. Med Sci Sports Exerc 2007;39:323-9.

88 Kenefick RW, Cheuvront SN, Palombo LJ, et al. Skin temperature modifies the impact of hypohydration on aerobic performance. J App/ Physiol 2010;109:79-86.

89 Merry TL, Ainslie PN, Cotter JD. Effects of aerobic fitness on hypohydration-induced physiological strain and exercise impairment. Acta Physiol (Oxf) 2010;198:179-90.

90 Sawka MN, Cheuvront SN, Kenefick RW. High skin temperature and hypohydration impair aerobic performance. Exp Physiol 2012;97:327-32.

91 Wall BA, Watson G, Peiffer JJ, et al. Current hydration guidelines are erroneous: dehydration does not impair exercise performance in the heat. $\mathrm{Br} J$ Sports Med Published Online First: 20 September 2013 doi:10.1136/bjsports-2013-092417.

92 Cohen D. The truth about sports drinks. BMJ 2012;345:e4737.

93 Adolph EF, Dill DB. Observations on water metabolism in the desert. Am J Physiol 1938;123:369-78.

94 Greenleaf JE, Sargent F. Voluntary dehydration in man. J App/ Physiol 1965;20:719-24

95 Greenleaf JE, Brock PJ, Keil LC, et al. Drinking and water balance during exercise and heat acclimation. J App/ Physiol 1983;54:414-19.

96 Armstrong LE, Costill DL, Fink WJ. Influence of diuretic-induced dehydration on competitive running performance. Med Sci Sports Exerc 1985;17:456-61.

97 Greenleaf JE. Problem: thirst, drinking behavior, and involuntary dehydration. Med Sci Sports Exerc 1992;24:645-56.

98 Cheuvront SN, Haymes EM. Ad libitum fluid intakes and thermoregulatory responses of female distance runners in three environments. J Sports Sci 2001;19:845-54.

99 Zouhal H, Groussard C, Minter G, et al. Inverse relationship between percentage body weight change and finishing time in 643 forty-two-kilometre marathon runners. Br J Sports Med 2011;45:1101-5.

100 Noakes TD, Goodwin N, Rayner BL, et al. Water intoxication: a possible complication during endurance exercise. Med Sci Sports Exerc 1985;17:370-5.

101 Noakes TD. Overconsumption of fluids by athletes. BMJ 2003;327:113-14

102 Almond CSD, Shin AY, Fortescue EB, et al. Hyponatremia among runners in the Boston Marathon. N Engl J Med 2005:352:1550-6.

103 Institute of Medicine (US). Dietary reference intakes for water, potassium, sodium, chloride, and sulfate. Washington DC: The National Academies Press, 2004:73-423.

104 Cheuvront SN, Carter R, Montain SJ, et al. Daily body mass variability and stability in active men undergoing exercise-heat stress. Int I Sport Nutr Exerc Metab 2004; 14:532-40.

105 Cheuvront SN, Ely BR, Kenefick RW, et al. Biological variation and diagnostic accuracy of dehydration assessment markers. Am J Clin Nutr 2010;92:565-73.

106 Cheuvront SN, Kenefick RW, Charkoudian N, et al. Physiologic basis for understanding quantitative dehydration assessment. Am J Clin Nutr 2013;97:455-62.

107 Cheuvront SN, Montain SJ, Goodman DA, et al. Evaluation of the limits to accurate sweat loss prediction during prolonged exercise. Eur J Appl Physiol 2007;101:215-24

108 Adams WC, Fox RH, Fry AJ. Thermoregulation during marathon running in cool, moderate, and hot environments. J Appl Physiol 1975;38:1030-37.

109 Bergeron MF, Armstrong LE, Maresh CM. Fluid and electrolyte losses during tennis in the heat. Clin Sports Med 1995;14:23-32.

110 Bergeron MF, Maresh CM, Armstrong LE, et al. Fluid-electrolyte balance associated with tennis match play in a hot environment. Int I Sport Nutr 1995:5:180-93.

111 Shirreffs SM, Sawka MN, Stone M. Water and electrolyte needs for football training and match-play. J Sports Sci 2006;24:699-707.

112 Shapiro Y, Pandolf KB, Goldman RF. Predicting sweat loss response to exercise, environment and clothing. Eur J Appl Physiol Occup Physiol 1982;48:83-96.

113 Barr SI, Costill DL. Water: can the endurance athlete get too much of a good thing? J Am Diet Assoc 1989;89:1629-32, 1635.

114 Montain SJ, Cheuvront SN, Sawka MN. Exercise associated hyponatraemia: quantitative analysis to understand the aetiology. $\mathrm{Br} J$ Sports Med 2006:40:98-105. Discussion 98-105.

115 Gonzalez RR, Cheuvront SN, Montain SJ, et al. Expanded prediction equations of human sweat loss and water needs. J App/ Physiol 2009;107:379-88.

116 Gonzalez RR, Cheuvront SN, Ely BR, et al. Sweat rate prediction equations for outdoor exercise with transient solar radiation. J Appl Physiol 2012:112:1300-10

117 Jay 0 , Webb P. Improving the prediction of sweat losses during exercise. J Appl Physiol 2009;107:375-6.

118 Costill DL. Sweating: its composition and effects on body fluids. Ann N Y Acad Sci 1977:301:160-74.
119 Verde T, Shephard RJ, Corey P, et al. Sweat composition in exercise and in heat. J Appl Physiol 1982;53:1540-5.

120 Bergeron MF. Muscle cramps during exercise - is It fatigue or electrolyte deficit? Curr Sports Med Rep 2008;7:S50-5.

121 Casa DJ. Exercise in the heat. II. Critical concepts in rehydration, exertional heat illnesses, and maximizing athletic performance. J Athl Train 1999;34:253-62.

122 Duvillard von SP, Braun WA, Markofski M, et al. Fluids and hydration in prolonged endurance performance. Nutrition 2004;20:651-6.

123 Sawka MN, Burke LM, Eichner ER, et al. American College of Sports Medicine. American College of Sports Medicine position stand. Exercise and fluid replacement. Med Sci Sports Exerc 2007;39:377-90.

124 Bergeron MF. Heat cramps: fluid and electrolyte challenges during tennis in the heat. J Sci Med Sport 2003;6:19-27.

125 Burke LM, Hawley JA, Wong SHS, et al. Carbohydrates for training and competition. J Sports Sci 2011;29(Suppl 1):S17-27.

126 Shirreffs SM, Maughan RJ. Volume repletion after exercise-induced volume depletion in humans: replacement of water and sodium losses. Am J Physiol 1998;274:F868-75.

127 Febbraio MA, Snow RJ, Stathis CG, et al. Effect of heat stress on muscle energy metabolism during exercise. J Appl Physiol 1994;77:2827-31.

128 González-Alonso J, Calbet JA, Nielsen B. Metabolic and thermodynamic responses to dehydration-induced reductions in muscle blood flow in exercising humans. J Physiol 1999;520(Pt 2):577-89.

129 Burke LM. Nutritional needs for exercise in the heat. Comp Biochem Physiol Part A Mol Integr Physiol 2001;128:735-48.

130 Ivy JL, Katz AL, Cutler CL, et al. Muscle glycogen synthesis after exercise: effect of time of carbohydrate ingestion. J App/ Physiol 1988;64:1480-5.

131 James L. Milk protein and the restoration of fluid balance after exercise. Med Sport Sci 2012;59:120-6.

132 Beelen M, Burke LM, Gibala MJ, et al. Nutritional strategies to promote postexercise recovery. Int I Sport Nutr Exerc Metab 2010;20:515-32.

133 Pritchett K, Pritchett R. Chocolate milk: a post-exercise recovery beverage for endurance sports. Med Sport Sci 2012;59:127-34.

134 Booth J, Marino F, Ward JJ. Improved running performance in hot humid conditions following whole body precooling. Med Sci Sports Exerc 1997;29:943-9.

135 González-Alonso J, Teller C, Andersen SL, et al. Influence of body temperature on the development of fatigue during prolonged exercise in the heat. J Appl Physiol 1999:86:1032-9.

136 Quod MJ, Martin DT, Laursen PB, et al. Practical precooling: effect on cycling time trial performance in warm conditions. J Sports Sci 2008;26:1477-87.

137 Duffield R, Green R, Castle $\mathrm{P}$, et al. Precooling can prevent the reduction of self-paced exercise intensity in the heat. Med Sci Sports Exerc 2010;42:577-84.

138 Ihsan $M$, Landers $\mathrm{G}$, Brearley $\mathrm{M}$, et al. Beneficial effects of ice ingestion as a precooling strategy on 40-km cycling time-trial performance. Int J Sports Physiol Perform 2010;5:140-51.

139 Ross MLR, Garvican LA, Jeacocke NA, et al. Novel precooling strategy enhances time trial cycling in the heat. Med Sci Sports Exerc 2011;43:123-33.

140 Siegel R, Maté J, Watson G, et al. Pre-cooling with ice slurry ingestion leads to similar run times to exhaustion in the heat as cold water immersion. J Sports Sci 2012;30:155-65.

141 Marsh D, Sleivert G. Effect of precooling on high intensity cycling performance. Br J Sports Med 1999:33:393-7.

142 Duffield R, Marino FE. Effects of pre-cooling procedures on intermittent-sprint exercise performance in warm conditions. Eur J Appl Physiol 2007;100:727-35.

143 Castle P, Mackenzie RW, Maxwell N, et al. Heat acclimation improves intermittent sprinting in the heat but additional pre-cooling offers no further ergogenic effect. J Sports Sci 2011;29:1125-34.

144 Minett GM, Duffield R, Marino FE, et al. Volume-dependent response of precooling for intermittent-sprint exercise in the heat. Med Sci Sports Exerc 2011:43:1760-9.

145 Brade C, Dawson B, Wallman K. Effects of different precooling techniques on repeat sprint ability in team sport athletes. Eur J Sport Sc 2014;14(Suppl 1): S84-91.

146 Duffield R, Dawson B, Bishop D, et al. Effect of wearing an ice cooling jacket on repeat sprint performance in warm/humid conditions. $\mathrm{Br}$ J Sports Med 2003;37:164-9.

147 Cheung S, Robinson A. The influence of upper-body pre-cooling on repeated sprint performance in moderate ambient temperatures. J Sports Sci 2004;22:605-12.

148 Brade C, Dawson B, Wallman K. Effect of precooling and acclimation on repeat-sprint performance in heat. J Sports Sci 2013;31:779-86.

149 Sleivert GG, Cotter JD, Roberts WS, et al. The influence of whole-body vs. torso pre-cooling on physiological strain and performance of high-intensity exercise in the heat. Comp Biochem Physiol Part A Mol Integr Physiol 2001;128:657-66.

150 Castle PC, Macdonald AL, Philp A, et al. Precooling leg muscle improves intermittent sprint exercise performance in hot, humid conditions. J App/ Physiol 2006;100:1377-84. 
151 Marino FE. Methods, advantages, and limitations of body cooling for exercise performance. Br J Sports Med 2002;36:89-94.

152 Quod MJ, Martin DT, Laursen PB. Cooling athletes before competition in the heat: comparison of techniques and practical considerations. Sports Med 2006;36:671-82.

153 Duffield R. Cooling interventions for the protection and recovery of exercise performance from exercise-induced heat stress. Med Sport Sci 2008;53:89-103.

154 Jones PR, Barton C, Morrissey D, et al. Pre-cooling for endurance exercise performance in the heat: a systematic review. BMC Med 2012;10:166.

155 Siegel R, Laursen PB. Keeping your cool: possible mechanisms for enhanced exercise performance in the heat with internal cooling methods. Sports Med 2012;42:89-98.

156 Ross $\mathrm{M}_{1}$ Abbiss $C_{\text {, Laursen }} \mathrm{P}$, et al. Precooling methods and their effects on athletic performance : a systematic review and practical applications. Sports Med 2013;43:207-25.

157 Tyler CJ, Sunderland C, Cheung SS. The effect of cooling prior to and during exercise on exercise performance and capacity in the heat: a meta-analysis. $\mathrm{Br} J$ Sports Med 2015;49:7-13.

158 Bongers CCWG, Thijssen DHJ, Veltmeijer MTW, et al. Precooling and percooling (cooling during exercise) both improve performance in the heat: a meta-analytical review. Br J Sports Med 2015;49:377-84.

159 Morrison SA, Cheung S, Cotter JD. Importance of airflow for physiologic and ergogenic effects of precooling. J Athl Train 2014;49:632-9.

160 Leeder J, Gissane C, van Someren K, et al. Cold water immersion and recovery from strenuous exercise: a meta-analysis. Br J Sports Med 2012;46:233-40.

161 DeGroot DW, Gallimore RP, Thompson SM, et al. Extremity cooling for heat stress mitigation in military and occupational settings. J Thermal Biol 2013;38:305-10.

162 Versey NG, Halson SL, Dawson BT. Water immersion recovery for athletes: effect on exercise performance and practical recommendations. Sports Med 2013;43:1101-30

163 Cotter JD, Sleivert GG, Roberts WS, et al. Effect of pre-cooling, with and without thigh cooling, on strain and endurance exercise performance in the heat. Comp Biochem Physiol Part A Mol Integr Physiol 2001;128:667-77.

164 Arngrimmsson SA, Petitt DS, Stueck MG, et al. Cooling vest worn during active warm-up improves 5-km run performance in the heat. J Appl Physio/ 2004;96:1867-74.

165 Cheuvront SN, Kolka MA, Cadarette BS, et al. Efficacy of intermittent, regional microclimate cooling. J Appl Physiol 2003;94:1841-8.

166 Lee JKW, Shirreffs SM, Maughan RJ. Cold drink ingestion improves exercise endurance capacity in the heat. Med Sci Sports Exerc 2008;40:1637-44.

167 Byrne C, Owen C, Cosnefroy A, et al. Self-paced exercise performance in the heat after pre-exercise cold-fluid ingestion. J Athl Train 2011;46:592-9.

168 Lee JKW, Shirreffs SM. The influence of drink temperature on thermoregulatory responses during prolonged exercise in a moderate environment. I Sports Sci 2007;25:975-85.

169 Lee JKW, Maughan RJ, Shirreffs SM. The influence of serial feeding of drinks at different temperatures on thermoregulatory responses during cycling. I Sports Sci 2008;26:583-90.

170 Bain AR, Lesperance NC, Jay O. Body heat storage during physical activity is lower with hot fluid ingestion under conditions that permit full evaporation. Acta Physiol (Oxf) 2012;206:98-108.

171 Morris NB, Bain AR, Cramer MN, et al. Evidence that transient changes in sudomotor output with cold and warm fluid ingestion are independently modulated by abdominal, but not oral thermoreceptors. J Appl Physiol 2014;116:1088-95.
172 Siegel R, Maté J, Brearley MB, et al. Ice slurry ingestion increases core temperature capacity and running time in the heat. Med Sci Sports Exerc 2010;42:717-25.

173 Yeo ZW, Fan PWP, Nio AQX, et al. Ice slurry on outdoor running performance in heat. Int I Sports Med 2012;33:859-66.

174 Stevens CJ, Dascombe B, Boyko A, et al. Ice slurry ingestion during cycling improves Olympic distance triathlon performance in the heat. J Sports SCi 2013:31:1271-9.

175 Stanley J, Leveritt M, Peake JM. Thermoregulatory responses to ice-slush beverage ingestion and exercise in the heat. Eur J Appl Physiol 2010;110:1163-73.

176 Duffield R, Coutts A, McCall A, et al. Pre-cooling for football training and competition in hot and humid conditions. Eur J Sport Sci 2013;13:58-67.

177 Duffield R, Steinbacher G, Fairchild TJ. The use of mixed-method, part-body pre-cooling procedures for team-sport athletes training in the heat. J Strength Cond Res 2009;23:2524-32.

178 Yeargin SW, Casa DJ, McClung JM, et al. Body cooling between two bouts of exercise in the heat enhances subsequent performance. J Strength Cond Res 2006;20:383-9.

179 Peiffer JJ, Abbiss CR, Watson G, et al. Effect of a 5-min cold-water immersion recovery on exercise performance in the heat. $B r$ I Sports Med 2010;44:461-5.

180 Vaile J, O'Hagan C, Stefanovic B, et al. Effect of cold water immersion on repeated cycling performance and limb blood flow. Br I Sports Med 2011;45:825-9.

181 Hornery DJ, Papalia S, Mujika I, et al. Physiological and performance benefits of halftime cooling. J Sci Med Sport 2005;8:15-25.

182 Lee JKW, Yeo ZW, Nio AQX, et al. Cold drink attenuates heat strain during work-rest cycles. Int I Sports Med 2013:34:1037-42.

183 Armstrong LE, Casa DJ, Millard-Stafford M, et al; American College of Sports Medicine. American College of Sports Medicine position stand. Exertional heat illness during training and competition. Med Sci Sports Exerc 2007;39:556-72.

184 Budd GM. Wet-bulb globe temperature (WBGT) - its history and its limitations. J Sci Med Sport 2008;11:20-32.

185 Gonzalez RR. Biophysics of heat exchange and clothing: applications to sports physiology. Med Exerc Nutr Health 1995;4:290-305.

186 Aughey RJ, Goodman CA, Mckenna MJ. Greater chance of high core temperatures with modified pacing strategy during team sport in the heat. I Sci Med Sport 2014;17:113-18.

187 Gosling CM, Gabbe BJ, McGivern J, et al. The incidence of heat casualties in sprint triathlon: the tale of two Melbourne race events. I Sci Med Sport 2008;11:52-7.

188 Sartor F, Snacken R, Demuth C, et al. Temperature, ambient ozone levels, and mortality during summer 1994, in Belgium. Environ Res 1995;70:105-13.

189 Byrne C, Lee JKW, Chew SAN, et al. Continuous thermoregulatory responses to mass-participation distance running in heat. Med Sci Sports Exerc 2006:38:803-10.

190 Roberts WO. Exertional heat stroke during a cool weather marathon: a case study. Med Sci Sports Exerc 2006:38:1197-203.

191 Sonna LA, Wenger CB, Flinn S, et al. Exertional heat injury and gene expression changes: a DNA microarray analysis study. J Appl Physiol 2004;96:1943-53.

192 Roberts WO. Determining a "do not start" temperature for a marathon on the basis of adverse outcomes. Med Sci Sports Exerc 2010;42:226-32. 


\section{BJSM Consensus recommendations on training and competing in the heat}

S Racinais, J M Alonso, A J Coutts, A D Flouris, O Girard, J

González-Alonso, C Hausswirth, O Jay, J K W Lee, N Mitchell, G P

Nassis, L Nybo, B M Pluim, B Roelands, M N Sawka, J Wingo and J D

Périard

Br J Sports Med published online June 11, 2015

Updated information and services can be found at:

http://bjsm.bmj.com/content/early/2015/06/11/bjsports-2015-094915

References

Open Access

Email alerting service
These include:

This article cites 184 articles, 58 of which you can access for free at: http://bjsm.bmj.com/content/early/2015/06/11/bjsports-2015-094915 \#BIBL

This is an Open Access article distributed in accordance with the Creative Commons Attribution Non Commercial (CC BY-NC 4.0) license, which permits others to distribute, remix, adapt, build upon this work non-commercially, and license their derivative works on different terms, provided the original work is properly cited and the use is non-commercial. See: http://creativecommons.org/licenses/by-nc/4.0/

Receive free email alerts when new articles cite this article. Sign up in the box at the top right corner of the online article.

Topic Articles on similar topics can be found in the following collections Collections

\section{Notes}

To request permissions go to:

http://group.bmj.com/group/rights-licensing/permissions

To order reprints go to:

http://journals.bmj.com/cgi/reprintform

To subscribe to BMJ go to:

http://group.bmj.com/subscribe/ 